\title{
SHARIA-BASED REGIONAL REGULATIONS AND INTER-RELIGIOUS RELATIONS IN BULUKUMBA SOUTH SULAWESI
}

\author{
Ashadi L. Diab \\ Kendari State Institute of Islamic Studies \\ ldiab_adhy@yahoo.com
}

\begin{abstract}
The background for the emergence of the idea of applying Sharia based regional regulations in Bulukumba is influenced by three factors: history, politics and socio-religious reality of the community. The response to the application of Islamic law also varies. At least in broad outline there are four kinds of responses, i.e. accepting, accepting with certain conditions, refusing then accepting and refusing. The application of Islamic law in Bulukumba has caused changes both in the physical appearance and socio-religious interaction of the people. Changes in physical appearance can be seen from the increasing number of women wearing hijab and a number of writings of religious nuances in various corners of the city. Changes in the areas of social interaction can be seen from the decrease of the crime rate. In the interaction between religious communities, the Sharia-based regulations are a medium for the Islamization of society. The existence of such legislation has also left no space for non-Muslims to build or add a new place of worship.
\end{abstract}

Keywords: sharia, Islamic law, regulation, Bulukumba.

\section{INTRODUCTION}

Efforts to enforce Islamic Law in Indonesia, both in a legal (constitutional) way which is through politics and illegal such as rebellion, are part of a long history of struggle of the Muslims of Indonesia to implement Islamic Law. However, social and political reality indicates that the idea has never received the support of the majority of the Muslims. Many observers consider it strange, given Indonesia is a country with the world's largest Islamic followerss. For them, how is it possible in the predominantly Muslim country that the idea of implementing Islamic Law does not ever receive majority support?

When this country was about to proclaim its independence in 1945, the discourse of Sharia law emerged. The idea proposed by the independence fighters among Islamic students faced a very strong opposition from of Islamic 
Nationalist fighters. Considering the integrity of the nation, the Islamic student fighters finally accepted the type of a country which is not a religious state. ${ }^{1}$ This event is the biggest sacrifice of Muslims in Indonesia's history.

In the Indonesian context, the idea of Islamic Law encountered mixed attitude in the community. The group that supported it always accused the others as lacking faith, ignoring Islamic Law and being influenced by Western views. Those who were against the idea always argued that the other group was outdated, old-fashioned, and had no ideas about the world of Islam. Each group always positioned itself in the opposite direction that it seemed impossible to build a dialogue to develop a shared vision or understanding of each other's opinions ${ }^{2}$. However, despite the fact that the supporters and opponents of the application of Islamic Law had a different view, they remained in the corridors of mutual respect for each other.

Along with changes from centralized to decentralized governance, where each region is given greater authority to regulate its respective areas, the demand for enforcing Islamic Law formally is on the rise as in the case of Bulukumba in South Sulawesi. Bulukumba, one of the regencies in the province of South Sulawesi, is known as a region with devout Muslims, and the idea of enforcing Islamic Law was initiated by the Preparatory Committee for Enforcement of Islamic Law (KPPSI). ${ }^{3}$

After the proclamation of independence, there was a debate about the basic guidelines of the country between religious groups who wanted Islam as the state ideology and nationalist groups that did not want the country to be based on religion. With great wisdom and based on the spirit of sacrifice, the Muslim groups finally agreed not to make Islam the state ideology and consented to the elimination of seven words, "the obligation to enforce Islamic teachings for its followers" from the Jakarta Charter on July 22, 1945.

The result of this compromise was not readily accepted by all the Indonesian people. Some groups resisted, such as the movement of DI/TII led by Colonel Kahar Muzakkar, but in the end, all forms of resistance were put down by the government. ${ }^{4}$ The momentum to re-enforce Islamic Law occurred again when

${ }^{1}$ Pupils are Muslim group that wants Islam as the foundation of the Republic of Indonesia, and the Nationalists are groups that want to separate between the state with religion (Secular), this definition can also be seen in Suhelmi Ahmad, the Islamic State Debate: Soekarno versus Natsir.

${ }^{2}$ Endang Saefuddin Anshari, 1983, Piagam Jakarta 22 June 1945, (Bandung: Pustaka), p. 60 .

${ }^{3}$ KPPSI stands for Komite Persiapan Penegakan Syariat Islam (Preparatory Committee for Enforcement of Islamic Law), but now has changed to KPSI (Komite Pengakan Syariat Islam -- Committee for Enforcement of Islamic Law).

${ }^{4}$ Ibid 
the New Order regime collapsed and was replaced by the reform government. Democracy is widely open under a decentralized system of government where each region has a greater opportunity to reorganize their respective administration. Eventually, Bulukumba became the first district in South Sulawesi to apply Islamic Law which is characterized by the issuance of four regulations on the literacy of the Qur'an, Muslim clothing, alms, and ban on alcoholic beverages.

Imposition of Islamic Law in Bulukumba, South Sulawesi receives a lot of support from diverse elements of society, including non-Muslims, but there are some Muslims / scholars who disagree with the idea. The support from non-Muslim groups regarding the application of Islamic Law on the one hand and the rejection of Islamic Law by some Muslims clearly raise a big question. Under such socio-religious conditions, Bulukumba is a region that is unique to be studied.

By reviewing the people's response to the application of Islamic Law in Bulukumba, it will be known whether the idea is just the desire of religious and political elites or the people of Bulukumba. Of course, other factors that must also be taken into account with regard to the implementation of such policy is the impact of the application of Islamic Law on socio-religious conditions of society, whether or not it is getting better or worse, especially regarding the relationship between people of different religions.

This paper is based on the assumption that the dissent against the imposition of Islamic Law is due to differences in how to understand and observe Islamic Law. Differences in the social, cultural and intellectual aspects have a very significant influence in determining the form of one's understanding of the Sharia. Therefore, even though every Muslim admits the truth of the principles of the Sharia, their understanding on the technical and operational level is different. The emergence of various schools of fiqh and theology, for example, shows that Islamic Law is interpreted differently and therefore, there can be no single view of the Sharia is once for all.

Sociologically, there are five centers of life outside the family: the educational environment, workplace, mosques, recitals institutions, religious organizations. ${ }^{5}$ Whether or not a person has a strong affiliation with the five centers or any one of them, will determine the pattern of thought and nature of that person. Similarly, changes to the system of each center of life above will also influence the change of thought.

${ }^{5}$ Abdul Munir Mulkhan, 1992, Runtuhnya Mitos Politik Santri, (Yogyakarta: Sipres), p.3. 
To the reconstructionists, such as Azyumardi Azra, the model of Sharia known today, must first be reviewed before being enforced as not every law is of the divine product which is sacred or transcendental in nature. According to the group, the majority of the Sharia known today is the product of historical and social conditions and hence profane and temporal. Sharia profanity provides spaces for dialog with the present conditions. Profanity within the scope of a community indicates that there are a wide variety of interests and values. The values that live in a society are constantly changing according to the changing interests through functional debate that generates a variety of new equilibrium forms.

Community is a stable system of groups working together in which there is consensus. Community is a system that consists of parts that are interconnected and in need of each other that give birth to balanced relations. ${ }^{6}$ The flow of functionalism sees the community as a social relation of all the institutions in it. Each part of an interdependent community, in the sense that the relationship between the communities is very close so changes in one part will affect the other. Disagreement will give birth to a new negotiation pattern that forms the balance of relationship within the community.

Likewise, the presence of regulations based on Islamic Law in Bulukumba, does not appear by itself but through a process as proposed in Berger's theory of social construction, externalization, objectivization and internalization. Through this process we will be able to understand the phenomenon of the existence of Sharia-based ragulations in Bulukumba.

According to Arskal Salim quoting Price (1999), the implementation of Islamic Law by the state can be divided into five levels: first, issues of family law, such as marriage, divorce and inheritance; second, economic and financial matters, such as Islamic banking and charity; third, religious practices (rituals), such as the obligation for a Muslim woman to wear a head cover; or an official ban on things that conflict with the teachings of Islam, such as alcohol and gambling; fourth, application of Islamic criminal law, especially related to the types of sanctions for violators; fifth, the use of Islamic law as the basis of the state and government systems. According to him, the higher the demand for implementing Islamic Law, the closer the establishment of an Islamic state. This article is very helpful to see how the regulations based on Islamic Law work in the system of government in Bulukumba and at at what level such regulations work.

Islamic history shows that broadly there are two opposite poles of schools

${ }^{6}$ Robert K. Merton, 1957, Social Theory and Social Structure, (Chicago, the Free Press of Glencoe); see also Talcot Parsons, 1951, The Social System, (Chicago, Free Press) 
of thought about how to apply Islamic Law in the social domain. Both poles are: first, al-Islamu huwa addhin wa ad-daulah (Islam is religion and state). This group has the view that Islam should be formally applied. The effect of this view is the birth of concepts that have the label of Islam such as Islamic Economics, Islamic Bank, etc. Second, al-islamu huwa addhin, wa daulah alwasilah (Islam is religion, and power is merely intermediate). Religion and power are different. This group relatively rejects all forms that have Islamic labels. To this group, the most important thing is not the label of Islam but the application of Islamic values.

\section{ISLAMIC DIALECTICS AND PATUNTUNG FAITH IN BULUKUMBA}

Bulukumba community in particular, has a religious belief that is very close to the sciences of Sufism and tariqat i.e. the Patuntung faith. The Patuntung faith is said to be a syncretic belief, because in addition to having some requirements of a Abrahamic religions such as belief in Almighty God as creator of the universe, the prophets, the scriptures and the day of judgment, people still believe in animism and dynamism. The Patuntung faith believes in three Gods, which are called Karaeng Ampatama as the creator of nature and live in the sky, Karaeng Kannuang Kammaya as sustainer of nature who live in Tompo Tika (the peak of Mount Bawakaraeng), and Karaeng Patanna Lino as an auxiliary to Karaeng Kannuang Kammaya whose task is to look after humans on earth. Karaeng Patanna Lino is also called pattakok. In addition, the Patuntung believe in Puang Loheta (God of many) found in every family, home and kingdom. ${ }^{7}$

A prophet in the Patuntung faith is Amma Towa who is the first leader in the belief, whose intelligence to write scriptures. The Scripture is called Patuntung (guidance) which is a guideline for every believer in practicing the rules of spirituality. In addition to the rules of spiritual teachings, this book also contains spells that can be used for treatment, various codes of dress, baths, and marriage. The Patuntung also has a concept of nature consisting of three forms of cosmology, i.e. the upper world called botinglangi, middle world called lino which is inhabited by humans, and lower world called paratiwi which is regarded as being under water. Each world has inhabitants. They affect each other and the influence could also affect humans. ${ }^{8}$

In Bulukumba, there is also a very traditional area known as Kajang. The Kajang

7 Syamsul al-Maarif al-Amien, 2003, Religious Freedom in Indonesia: The Constitution, Islamization and the Ammatoa of Sulawesi, Thesis, Center for Religious and Cross Cultural Studies, Yogyakarta. 
community has belief based on tradition, i.e. Pasanga ri Kajang. Pasanga ri Kajang is the religious teachings of ancient community of Kajang in the form of oral tradition of revelation or divine message passed down orally through Amma Toa that contains morality of religious teachings which are still firmly held by the Kajang community.

The oral tradition, called Pasanga ri Kajang, to the people of Kajang is a knowledge system that contains a variety of cultural values, which serve as the main reference in the living a life in this world, both in relation to theological matters, relationship with fellow human beings, and relationship with the natural surroundings which Datuk ri Tiro took into consideration in spreading the Islamic religion in Bulukumba. Datuk ri Tiro's success in spreading Islam in Bulukumba was because he always honored tradition of the people and not to impose rigid application of Sharia.

Datuk ri Tiro's expertise in the field of Sufism is served as the basis for spreading Islam in Bulukumba. Sufism which he used in spreading Islam makes it easier to communicate and teach Islam in this region. This is because the people of Bulukumba had already been very familiar with the teachings associated with Sufism and tariqat. ${ }^{9}$

Because of the condition of public confidence Bulukumba very close to the teachings of Sufism and congregations, often based on a presumption that the spread of Islam in Bulukumba no difficulty, but this assumption is not entirely correct. ${ }^{10}$ According to the story that developed in the middle of the community, especially the Kajang, that when Datuk ri Tiro enters the territory of the Kajang to broadcast the Islamic religion, he made a deal with the leader of the Kajang known as Amma Towa.

In Towa Amma it is mentioned that Datuk ri Tiro was allowed to spread the Islamic religion in this place, but previously had to challenge the magic power of the Amma Towa. Whoever loses must join the faith of the winner. This means that if Amma Towa lost, he had to convert to Islam including members of the community and vice versa. The contest of magic turned out to be a draw, nobody won and nobody lost.

Since it was a draw, one had no compulsion to follow the other. The above is proved by the existence of the Kajang people that have symbolically converted to Islam, but the implementation and the meaning of Islam is very different from what is generally understood since the feel of Sharia is very

${ }^{9}$ Samiang Katu, 2000, Pasang ri Kajang: Kajian tentang Akomodasi Islam dengan Budaya Lokal di Sulawesi Selatan, (Pusat Pengkajian Islam dan Masyarakat (PPIM) IAIN Alauddin Makassar), p.57.

${ }^{10} \mathrm{Ibid}$. 
strong. The Kajang people give Sufism and morality far more attention than Sharia. Therefore, although the Kajang community has embraced Islam, they still observe the tradition which cling to the teachings of Pasanga ri Kajang containing moral messages highly respected by the Kajang people.

In its development, the Kajang community is divided into two groups i.e. the exterior Kajang (assimilated) and the interior Kajang (indigenous). The exterior Kajang community refers to those who have undergone modernization and not too rigid in carrying out their customary traditions, particularly the values contained in the message of Pasanga ri Kajang, whereas the interior Kajang community still upholds the traditions and remains relatively untouched the modern world. As a rejection of the modern symbols, they do not want to use electricity as lighting, sandals as footwear, means of communication, etc.

\section{ISLAMIC LAW IN SOCIAL AND POLITICAL STRUGGLE}

The Sharia terminology is generally used in two senses, i.e. in a broad sense and in a narrow sense. In a broad sense, the Law is intended as the whole Islamic religious norms covering aspects of doctrinal and practical aspects. Meanwhile, in a narrow sense, the Sharia refers to the practical aspects of Islamic teachings, the part that consists of the norms that regulate human behavior such as worship, marriage, purchase and sales, litigation in the court, etc. If the term of Islamic Law is used to translate the term Sharia, it means the Law in its narrow sense. ${ }^{11}$

In the context of Indonesia, especially Bulukumba, where the majority of the population are Muslims, Islamic Law is thelaw that is commonly practiced and has been deeply rooted in the culture of Indonesian society. Therefore, Islamic Law in Indonesia is the living law or in Geertz's perspective, the values of Islam in Indonesia serve as a pattern of behavior. This phenomenon occurs not merely because Islam is a religion practiced by the majority of Indonesia's population, but also because of the dimensions of the application of Islamic Law that has become part of the tradition that is sometimes considered sacred.

Although the term Islamic Law is not the best translation of the word Sharia, in the context of positive law in Indonesia, the Islamic legal term is used mainly to differentiate it from customary law and Western law. This distinction shows that the law comas from the religion of Islam. Thus, its use at the operational level as the translation of the term for Sharia is not entirely wrong.

An understanding of Islamic Law should depart from the basic assumption that the real Islamic Law is not a detailed legal system that comes from

\footnotetext{
${ }^{11}$ Syamsul Anwar, Islamic Jurisprudence. op. cit., p. 134.
} 
Heaven and is not part of human history. As with other legal systems, Islamic Law is nothing but the result of human interaction with social and political conditions. Such an understanding is the basis for the necessity of sociological and historical approach in an attempt to photograph the opportunities and challenges for its application in society.

In the history of Islamic Law, there is strong evidence of how social context is very influential in determining the laws that arise. Among the jurists, for example, the dynamics of thinking between Shafi'i with his qaul qadim and qaul jadid, Malik with his maslahah mursalah, Abu Hanifah with his rational thinking, and Ibn Hambal with his traditional thinking (Salaf) show how their dialogic interaction with social context and with the place where they live in can affect and shape their understanding of the Sharia. ${ }^{12}$ Similarly, the customary practices in the society are also generally adopted by Islam as a means of preparing rules and regulations of Islamic Law, as long as the customary practices are not contrary to Islamic teachings contained in the Qur'an and the Sunnah of the prophet. ${ }^{13}$

In addition to sociological factors above, the political configuration of the country is also instrumental in changing the law. Dominant groups that are close to the political authorities are capable of gaining power to enforce certain laws and make other policies. Therefore, the saying that states "whoever rules will apply their school of thought" is not merely a slogan.

As evidence, when Ibn al-Muqaffa' (d. 139H / 756 AD) proposed legislation of Islamic Law to the Caliph Abu Ja'far al-Mansur (754-775 AD) who then ordered Malik ibn Anas to prepare and compile the law. The command or request was made twice, i.e. in the year $148 \mathrm{H} / 765 \mathrm{M}$ and $163 \mathrm{H} / 777 \mathrm{AD}$. At first Malik ibn Anas refused, but during the caliphate of Harun al-Rashid, he granted it. So, the book al-Muwatta' was written which was then made the official guidelines by the government in resolving legal issues. The Maliki school of thought was made official by the government because it was the dominant school at the time and was desired by the authorities.

When Islamic Law interacts and wishes to develop in the wider region, it will definitely be in contact with various local norms that vary widely based on the structure and culture embraced by a society. As a result, locally characterized legal products such as Hijazi Fiqh, Misri fiqh, Hindi fiqh emerged, and in Indonesian there was an idea of formulating the Indonesian fiqh.

${ }^{12}$ Muhammad Ali Sais, 1957, Tarikh al-Fiqh al-Islami (Mesir: Mathba’ah al-Nahda), p. 104; see also Husain Hamid Hasan, tt, al-Madkhal li Dirasat al-Fiqh al-Islami (Mesir: Mathba ah al-Nahdah), p. 33.

${ }^{13}$ Abd al-Rahman al-Shabuni, 1982, al-Mudkhal ila al-Fiqh wa Tarikh al-Tasyri al-Islami (Cairo: Dar al-Muslim), h. 138. 
In 1991, the need for the formulation of the Indonesian fiqh came into being with the issuance of the Presidential Instruction No. 1 of 1991 concerning the dissemination of the Compilation of Islamic Law in Indonesia (KHI), of which the formulation is identified as the Indonesian fiqh or Islamic jurisprudence with a distinctively Indonesian flavor. ${ }^{14}$

Seen through the political view of the Indonesian law, the emergence of the KHI can be regarded as the crowning achievement of Muslims at that time in the application of Islamic Law (in this case a family law) as a positive law. However, one thing worth noting is that the KHI legislation is not only the success of the Indonesian Ulema Council that represents Muslims, Ministry of Religious Affairs representing the government, and the Supreme Court representing holders of judicial power, but it is also due to the approval of the authorities, i.e. the politics of law and the political will of the state. The state in fact plays a crucial role in effecting the KHI legislation because it holds a monopoly in the law enforcement in community life. ${ }^{15}$ Beyond political motives, sociological and even economic background for the KHI policy, it can safely be said that the justification of state power serves as one of the keys to the application of Islamic Law.

On the other hand, outside of the political system, social configuration issues are also a determinant for the application of Islamic Law. Therefore, the application of Islamic Law in Indonesia always takes a pluralistic society into consideration. With such grounds, the implementation and enforcement of Islamic Law in the socio-political arena always encounters polemic Indonesia. 'Reduction' of Islamic Law is done in order to maintain commitment to the plurality of religions, so that Islamic Law imposed only concerns the field of law which does not threaten people of other faiths. That is why Islamic Law is gaining legitimacy and justification in the Indonesian legal system only in the legal field of muamalat (civil matters), excluding criminal law (jinayat). It even is only limited to the areas of inheritance, marriage and charity, needless to say.

By looking at the history of the law, in fact, the law is a political product of the nation. It means that the law is always related to politics. Hence, the wisdom of the law that emerged is the embodiment of the country's political wisdom. The important thing to note about this phenomenon is that the law is dependent

${ }^{14}$ Cik Hasan Bisri , "Pengembangan Wilayah Penelitian dan Pranata Sosial”, in Mimbar Hukum, Jurnal Ilmu Agama Islam, Bandung: IAIN Sunan Djati, No. I Year XXIII, September-December 1992, p. 92.

${ }^{15}$ Because of the dominance of the government in the process of formulating the Compilation of Islamic Law, for some observers, the KHI is considered a state project. See Marzuki Wahid and Rumadi op cit. 
on political factors. Whether or not Islamic Law can be applied is determined by the extent to which the political will of the country represented in official institutions that deal with the problem. Thus, holding the legal discourse cannot be separated from the social and political context of the country in which the law is created. In this regard, the character of a legal product is constantly influenced or determined by the political configuration that gives birth to it, meaning that certain political configuration of a dominant group always bears the character of certain legal products in accordance with its political vision. In addition, Islamic Law is also influenced by social development. Social changes that occur in a community, will directly or indirectly affect social institutions in various fields such as government, economics, education, religion, etc.

\section{BIRTH PROCESS OF ISLAMIC LAW-BASED REGIONAL REGULATIONS}

In the context of Bulukumba, enactment of some legislation based on Islamic Law should be responded wisely by putting on the assumption that every state policy (read: government) does not just emerge, but it is presented and made within the framework and the willingness of policy makers, in this case local government. The struggle of several Islamic organizations to formalize and legalize Islamic Sharia into the body of the state met with interest of the local government. In this context the theory of who uses who surfaces. On the one hand, local government wishes to attract public sympathy, but on the other hand it is used by proponents of formalization of Islamic Law.

The phenomenon of diversity in Indonesia which is a public concern is very interesting to observe. Since the autonomy and decentralization was implemented through regulation Act No. 22 of 1999 the strengthening of local dynamics continues to occur. In many regions, institutional restructuring (bureaucracy and parliament) and development initiatives thrive. This was also followed by the increased participation of civil society in various arenas. One of the crucial issues that arises in conjunction with local politics is strengthening of identity politics (local identity politics).

In the context of Islamic politics, autonomy and decentralization is the entrance to Islamization in all areas including through the enactment of legislation based on Islamic Law. Islamization agenda for Islamic political parties is being kept alive. It is the main reason the issue of Islamic Law is never abandoned Islamic political parties. ${ }^{16}$ Therefore, as stated by several historians (Benda, Ricklefs, and Azra), modern Indonesian history is a history that witnesses the

${ }^{16}$ http://Islamlib.com/id/index.php?page=article\&id=516, Arskal Salim, Daya Hid up Isu Syariat dalam Politik. Accessed on 19 May 2015 
ongoing deeper and sustainable Islamization. ${ }^{17}$

Regions that have implemented Regional Regulations based on Islamic Law are West Sumatera, South Kalimantan, East Nusa Tenggara, South Sulawesi, Eat Java and West Java. ${ }^{18}$ As for South Sulawesi, public attention is on Bulukumba. Bulukumba is the first Regency to issue Sharia-based regulations in South Sulawesi. Therefore, Bulukumba serves as a pilot project for implementing a law based on Islamic Law by the Government. Experiments of Sharia in Bulukumba are penetrating into lower level of the government: the village. A total of 12 villages have been used as a demonstration areas for the application of Islamic Law since the beginning of $2005 .{ }^{19}$ The Regency is also popular as a pioneer application of Islamic Law in South Sulawesi, and the South Sulawesi Muslim Congress III, in March 2005, was held in this area.

The implementation of Islamic Law in the villages as pilot project is growing very rapidly, even beyond the district and provincial legislation. Villages within the pilot project even implemented the hudud criminal law. Padang village, in Gantarang Subdistrict, for example, set the "rules of the village" which contain the rules on the offense of adultery (100 lashes), qadzaf or accusing someone of adultery ( 80 lashes or handed over to the police), liquor (40 lashes), and qishash (reply in kind) for physical abuse. ${ }^{20}$

\section{IMPLICATIONS OF THE APPLICATION OF SHARIA BASED REGIONAL REGULATIONS ON THE RELATIONSHIP BETWEEN RELIGIONS}

The application of Islamic Law in Bulukumba imposed through Sharia-based regulations gave birth to some implications in the socio-political-religious society of Bulukumba. The implications are as follows:

\section{a. Increased religious conversion}

The implementation of Sharia-based regulations affects non-Muslims whose total number is only about $0.12 \%$ amid Muslim community which reaches 99.88\%. The imposition of Sharia-based regulations has either directly or indirectly generated psychological pressure against non-Muslims. After the enforcement of such regulations, several religious conversions occurred, whereas before the regulations new converts were relatively non-existent. As reported by H.Sofyan, the Imam of Jami al-Hidayah Mosque:

\footnotetext{
${ }^{17}$ Ibid

${ }^{18}$ Taufik Adnan Amal and Samsul Rizal Panggabean, 2004, Politik Syariat Islam dari Indonesia hingga Nigeria, (Jakarta: Pustaka Alvabet), p. 82.

${ }^{19}$ Asrori S. Karni and Bernadetta Febriana, and Anthony, "Gelora Syariah Mengepung Kota" (Headline story, Gatra $25^{\text {th }}$ Edition, 1 May 2006)

${ }^{20}$ Ibid
} 
"After Sharia-based regulations were imposed, many people of Chinese descent converted to Islam whereas previously they rarely did. So it's good to have Sharia regulations, they became afraid. King motor [owner] has converted to Islam along with his family. During a Muslim congress, women who wanted to leave the house unveiled were immediately detained and told to wear the hijab because they were afraid of being detained."

The increased number of new converts after the imposition of legislation based on Islamic Law has raised suspicion, lest they embrace Islam not out of consciousness, rather out of fear of the imposition of Sharia-based regulations. Ideally, in fact, the new law applies only to Muslims, but concerns about the application of Islamic Law based regulations can serve as instrument to change one's religion.

\section{b. No Freedom of Religion for other Religious Followers to Build House of Worship}

A house of worship is very important for religious followers. The existence of houses of worship not only serves as a worship place for a certain religion but also as evidence of its existence. According to the rules of construction of houses of worship, the construction can be done if there is consent from the surrounding community. It means that if there is no consent from the local community then certainly there will be no construction of non-Muslim places of worship.

In fact, the number of non-Muslims in Bulukumba is more or less $0.12 \%$ but even so their need for a place of worship is a very important thing. However, the Sharia regulations have somehow generated disrespect for the existence of other religions which is characterized by difficulty for other religious followers to have a place of worship which then becomes a bad precedent for interfaith relations, as reported by $\mathrm{H}$. Sofyan:

"The relations between Muslims and non-Muslims are fine as long as they do not build (a new church). In the city of Bulukumba, there is only one church. There was an attempt of Christians to build a church, but it was directly protested by the community. Bulukumba people do not want a church to be constructed.

\section{CLOSING REMARKS}

The background for the emergence of the idea of applying Sharia based regional regulations in Bulukumba is influenced by three factors: history, politics and 
socio-religious reality of the community. The history of the local community which is plural becomes an important element in the process of the birth of such regulations. Political factors include the shift in the government system from centralization to decentralization (autonomous regions) in which the local government has authority to regulate its own area. Socio-religious reality of the community is also a major element in the idea of imposing Shariabased regulations. Degradation of people's morality and a growing lack of public knowledge of the Islamic religion (reading-writing of the Qur'an) also becomes one of the important aspects. However, the response to the application of Islamic law also varies. At least in broad outline there are four kinds of responses, i.e. accepting, accepting with certain conditions, refusing then accepting and refusing.

The application of Islamic law in Bulukumba has caused changes both in the physical appearance and socio-religious interaction of the people. Changes in physical appearance can be seen from the increasing number of women wearing hijab and a lot of writings of religious nuances in various corners of the city. Changes in the areas of social interaction can be seen from the decrease of the crime rate. In the interaction between religious communities, the Sharia-based regulations are a medium for the Islamization of society. It is evidenced by the fact that after the implementation of Sharia legislation, there were families converting to Islam. Their convert to Islam after the imposition of the legislation raises suspicion that they become Muslims simply for fear of the regulations. The existence of such legislation has also left no space for non-Muslims to build or add a new place of worship.

\section{REFERENCES}

Endang Saefuddin Anshari, 1983, Piagam Jakarta 22 Juni 1945, (Bandung: Pustaka), h. 60.

Syamsul al-Maarif al-Amien, 2003, Religious Freedom in Indonesia: The Constitution, Islamization and the Ammatoa of Sulawesi, Thesis, Center for Religiou and Cross Cultural Studies, Yogyakarta.

Samiang Katu, 2000, Pasang ri Kajang: Kajian tentang Akomodasi Islam dengan Budaya Lokal di Sulawesi Selatan, (Pusat Pengkajian Islam dan Masyarakat (PPIM) IAIN Alauddin Makassar), h.57.

Muhammad Ali Sais, 1957, Tarikh al-Fiqh al-Islami (Mesir: Mathba'ah al-Nahda), h. 104; lihat juga Husain Hamid Hasan, tt, al-Madkhal li Dirasat al-Fiqh al-Islami (Mesir: Mathba ah al-Nahdah), h. 33.

Abd al-Rahman al-Shabuni, 1982, al-Mudkhal ila al-Fiqh wa Tarikh al-Tasyri 
al-Islami (Kairo: Dar al-Muslim), h. 138.

Cik Hasan Bisri , "Pengembangan Wilayah Penelitian dan Pranata Sosial," dalam Mimbar Hukum, Jurnal Ilmu Agama Islam, Bandung: IAIN Sunan Djati, No. I Tahun XXIII, September-Desember 1992, h. 92.

Taufik Adnan Amal dan Samsul Rizal Panggabean, 2004, Politik Syariat Islam dari Indonesia hingga Nigeria, (Jakarta: Pustaka Alvabet), h. 82.

Asrori S. Karni dan Bernadetta Febriana, dan Anthony, "Gelora Syariah Mengepung Kota," (Laporan Utama, Gatra Edisi 25, 1 Mei 2006)

Abdul Munir Mulkhan, 1992, Runtuhnya Mitos Politik Santri, (Yogyakarta: Sipres), h.3.

Robert K. Merton, 1957, Social Theory and Social Structure, (Chicago, the Free Press of Glencoe); lihat juga Talcot Parsons, 1951, The Social System, (Chicago, Free Press)

http://Islamlib.com/id/index.php?page=article\&id=516, Arskal Salim, Daya Hidup Isu Syariat dalam Politik. Di akses tanggal 19 Mei 20015 